\title{
ECONOMICS
}

\section{THE IMPACTS OF STRUCTURAL TRANSFORMATION AND INDUSTRIAL UPGRADING ON REGIONAL INEQUALITY IN CHINA}

by

Tsun Se Cheong

and

Yanrui Wu

Business School

University of Western Australia 


\section{THE IMPACTS OF STRUCTURAL TRANSFORMATION AND}

INDUSTRIAL UPGRADING ON REGIONAL INEQUALITY IN CHINA

by

Tsun Se Cheong*, Yanrui Wu

Business School, University of Western Australia, 35 Stirling Highway, Perth, WA 6009, Australia

${ }^{*}$ Corresponding author. Tel.: +618 64885639

Email addresses: Tsun.Cheong@uwa.edu.au (T. S. Cheong), Yanrui.Wu@uwa.edu.au (Y. Wu).

DISCUSSION PAPER 14.09

Acknowledgements :We acknowledge James Ma for excellent research assistance, Australian Research Council (DP1092913) and the Fundamental Research Funds for the Central Universities(12JNYH002, via Jinan University, Guangzhou) for financial support and participants of CESA-Jinan University international conference (December 12-13, 2013) for helpful comments. 


\begin{abstract}
China has achieved unprecedented success in economic growth since the initiation of economic reforms. The high growth could partly be attributed to the success in structural transformation of the economy. Another contributing factor may be the industrial upgrading of the manufacturing sector towards high value-added products. However, regional inequality in China has increased considerably behind the scenes. In order to have sustainable economic growth, it is thus crucial to investigate both the impacts of structural transformation and industrial upgrading on regional inequality. This paper contributes to the literature in the analysis of the structural transformation by employing a database at the county-level. Decompositions are performed for different spatial groupings so as to provide a clear view of evolution of regional inequality. In addition, the contributions of the major industries to inequality in industrialization are examined by using a database of value-added at the provincial level. The results may have important policy implications for the formulation of a comprehensive and coherent strategy in managing inequality while promoting structural transformation and industrial upgrading.
\end{abstract}

Keywords: China, county-level, inequality, industrialization, structural transformation, industrial upgrading

JEL codes: D63, O10, O14, O15, O53 


\section{Introduction}

Following the initiation of economic reform in 1978, China has experienced rapid growth and is often cited as a 'miracle' in economic development. Gross domestic product (GDP) increased from 365 billion Yuan in 1978 to 47.3 trillion Yuan in 20II, whilst GDP per capita increased from 38I Yuan to 35181 Yuan in that period (State Statistical Bureau, 2012). Yu (2012) argues that this unprecedented growth could be attributed to the successes in structural transformation and industrial upgrading.

The strong economic growth has not only benefited China, but has also driven economic growth of nearby countries (Saari, 2007). Moreover, China's economic growth has contributed significantly to the decline of global inequality (Hung and Kucinskas, 20II) and global poverty (Dollar, 2007, Goh et al., 2009). However, regional inequality in China increased dramatically behind the scenes (Cheong, 2012a). Many scholars have argued that inequality can lead to different kinds of social dysfunction, such as crime, racism, drug abuse, mental illness, and loss of social capital and trust in society (see Wilkinson and Pickett, 2009, for a survey). Furthermore, many studies report that inequality is correlated with political instability (Muller and Seligson, 1987, Alesina and Perotti, 1996, Acemoglu and Robinson, 200I, Dutt and Mitra, 2008).

For the case of China, Zhuang (2008) warns that, 'The persistence of inequality and rising gaps in income and consumption between the rich and poor would make reforms more difficult; trigger social tensions; and pose a clear and present danger to social and political stability and, therefore, to the very sustainability of the growth process itself.' This argument is supported by the fact that the number of mass incidents in China (including protests, demonstrations and clashes with police) increased from 10000 in 1993 to 87000 in 2005 (Wen, 2007). Similarly, Wang and Hu (1999) suggest that inequality may lead to economic and social instability, and may even affect the unity of China. Cheong and $\mathrm{Wu}(2013 \mathrm{~b})$ also find that there is a positive correlation between regional inequality and crime rates in China. Therefore, it calls for an in-depth study on regional inequality so that policies can be formulated to mitigate inequality.

In fact, the problem of regional inequality has attracted the attention of researchers from different disciplines, and many studies have been carried out to examine regional inequality in China. However, most of the studies have been based on provincial level data, while only a few studies have investigated inequality using county-level data (Cheong, 20l2b). The main objective of this paper is to fill the void in the literature and provide a thorough examination of the impacts of structural transformation on regional inequality in China by using a county-level database. In the second part of this study, the focus will turn to industrialization itself, and the disparity in industrial upgrading will be 
evaluated through an examination of value-added of the major industries. Decompositions of inequality are performed in the vertical and horizontal directions. Decompositions are first applied vertically to different groupings at various spatial levels, while another set of decomposition is applied horizontally within each spatial level so as to determine the contributions of the different industrial sectors.

This paper is structured as follows. Section 2 presents a review of the literature and other relevant information on industrialization and industrial upgrading. Section 3 provides a discussion of the research methods. Section 4 describes data issues. Section 5 presents the findings and discussions. Further analysis at the industrial sub-sector level is reported in Section 6, while Section 7 concludes.

\section{Industrialization and Industrial Upgrading in China}

It is well known that a major feature of China's economic development is the dramatic change in sectoral composition of GDP due to structural transformation. The structural transform not only has radically altered the economic landscape of China, but also led to an increase in regional inequality. Cheong and $\mathrm{Wu}$ (2013a) employ generalized method of moments (GMM) estimator in their analysis, and they find that industrialization and tertiary industry development both exert positive effects on regional inequality in China.

Basically, all the economic activities in China can be categorized into three strata of industries, namely, the primary industry, which refers to agriculture, forestry, animal husbandry and fishery and services in support of these industries; the secondary industry, which refers to mining and quarrying, manufacturing, production and supply of electricity, water and gas, and construction; and the tertiary industry, which refers to all other economic activities not included in the primary or secondary industries (State Statistical Bureau, 2012).

Figure I shows the percentage composition of the primary industry has declined from $28.2 \%$ in 1978 to about $10 \%$ in $201 \mathrm{I}$ while the share of the secondary industry has remained more or less the same, being $47.9 \%$ in 1978 and $46.6 \%$ in 2011 . The percentage of tertiary industry increased substantially from $23.9 \%$ to $43.3 \%$ in that period. 


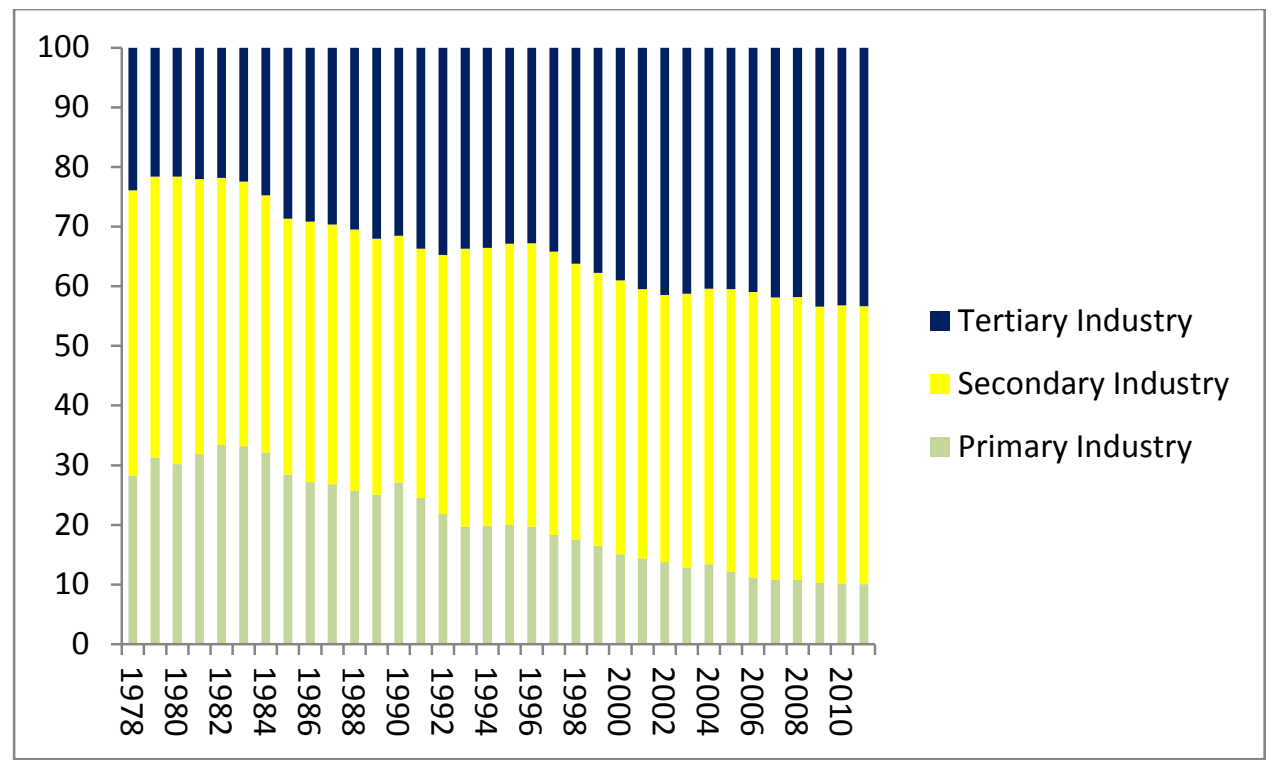

Figure 1 Percentage of contribution to GDP (current price) of the three sectors

Source: China Statistical Yearbook (2012).

Figure 2 shows the percentage composition of total employed persons. Reallocation of labor in large scale from primary sector to secondary and tertiary sectors can be observed. The percentage share of employed persons in the primary sector declined from $70.5 \%$ in 1978 to only $34.8 \%$ in 2011 . The change is so dramatic that the percentage share of the primary sector fell more than a half of its initial value in the reform era. By contrast, the share of the secondary sector increased from $17.3 \%$ to $29.5 \%$, whereas the percentage of the tertiary sector increased from $12.2 \%$ to $35.7 \%$.

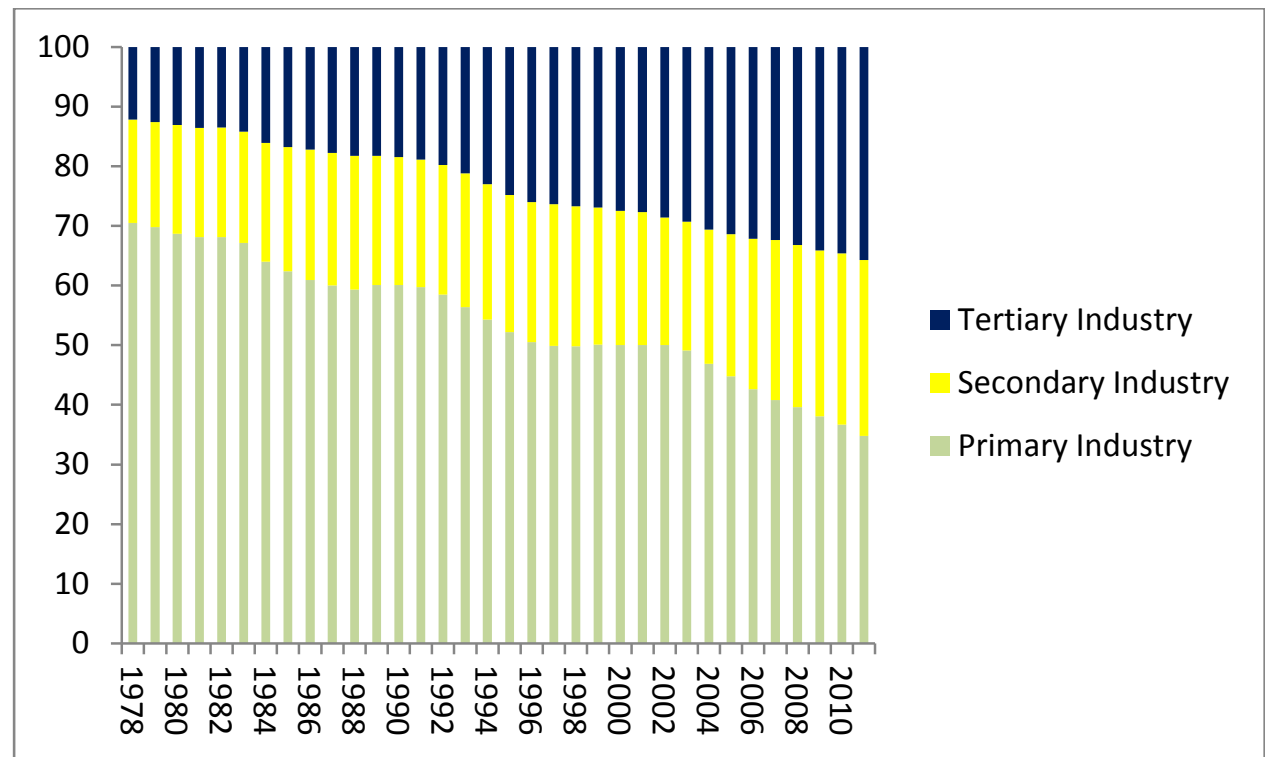

Figure 2 Percentage of total employed persons of the three sectors

Source: Authors' own calculation using data from China Statistical Yearbook (2012). 
Although the structural transformation in China was very successful and led to considerable improvement of the living standards of its people, however, inequality also increased substantially in this period. Huang et al. (2003) prove that development in the secondary sector is the largest contributor to the overall regional inequality in China. Therefore, our study mainly focuses on the impacts of industrialization on inequality.

According to Kuznets (1955), inequality always increases with industrialization in the early stage of economic development. Thus, it is often argued that an increase in regional inequality is inevitable for the promotion of economic growth and so it is necessary to bear the pain of inequality in the process. In fact, many researchers report that industrialization in China has increased output significantly but has also led to a surge in inequality (Rozelle, 1994, Rozelle, 1996, Tsui, 1996, Yao, 1997, Golley, 2002, Yang, 2002, Huang et al., 2003, Wan, 2004, Kanbur and Zhang, 2005, Tsui, 2007, Pradhan, 2009).

Rozelle (1994) points out that policies that helped agriculture could reduce inequality, while those that promoted rural industrialization would increase inequality. In another article, Rozelle (1996) claims that the increase in inequality could be attributed to the expansion of the industrial sector. By using factor decomposition Tsui (1996) finds that the industrial sector has played a central role in the rise of regional inequality. Golley (2002) suggests that industrial development has occurred at a very uneven pace across the provinces in China, leading to industrial agglomeration, which has been accompanied by an increase of regional disparities in gross regional product (GRP) per capita and growth rates. Yang (2002) suggests that in the pre-reform period, massive amounts of resources were extracted from the agricultural sector so as to accelerate the pace of industrialization and this strategy has led to an increase in inequality in China. Huang et al. (2003) find that unevenness in distribution of secondary industry amongst the provinces accounted for half of the overall inequality in China from 1991 to 200I. Kanbur and Zhang (2005) report that the increase in the ratio of heavy industry to gross output is positively correlated with inequality, especially, in the period from 1952 to 1978. Tsui (2007) shows that the difference in provincial share of secondary industry sector to national total led to disparity in growth, which in turn exacerbated inter-provincial inequality in China. Pradhan (2009) also shows that industrialization affected income inequality in China during 1952 2005.

It should be noted that the township and village enterprise (TVE) sector also plays a major role in rural industrialization in China. Several researchers study the impacts of rural industrialization on inequality by examining the effects of TVEs, and they report that the unequal development of TVEs exacerbated regional inequality in China (see Yao, 1997, Zhang, 1999, Wan, 2004). All studies mentioned above suggest that industrialization is the crux of the problem of regional inequality in China, therefore the focus of this paper is mainly on industrialization. 
In the process of industrialization, it is crucial to go through the process of industrial upgrading toward high value-added industries so as to increase total output and maintain a sustainable economic growth. In the beginning of the industrialization process, many developing countries would first rely on light industries, for example, textiles and food industries. The raw materials of these light industries are readily available from the agricultural sector; moreover, the skill requirement of the labour is not high for these industries. Therefore, these industries can be set up easily in the beginning of the industrialization process, and many developing countries rely on these industries heavily in the first stage of industrialization. However, with the continued improvement of human capital and technological level, economic development will then reach a bottleneck. In order to maintain economic growth, it is thus required to undergo industrial reform and upgrading so as to move toward high value-added industries.

Similar pattern can be observed from the industrialization in China. Figure 3 shows the change in percentage composition of total value-added for the major industries from 1993 to 2007. The data was compiled from the China Industrial Economic Statistical Yearbook, which provides the figures of value-added of 20 major industries from 1993 up to 2007. It can be observed that the percentage composition of the beverage manufacturing, tobacco processing, and textiles sectors fell in that period. By contrast, the high technological and high value-added sectors like transportation equipment manufacturing, electric equipment and machinery, as well as instruments and meters sectors, all of them registered an increase. It should be noted that the electronics and telecommunications sector has the highest growth in percentage composition; it rose from $3.74 \%$ in 1993 to $9.68 \%$ in 2007 which is equivalent to an increase of $158 \%$. 


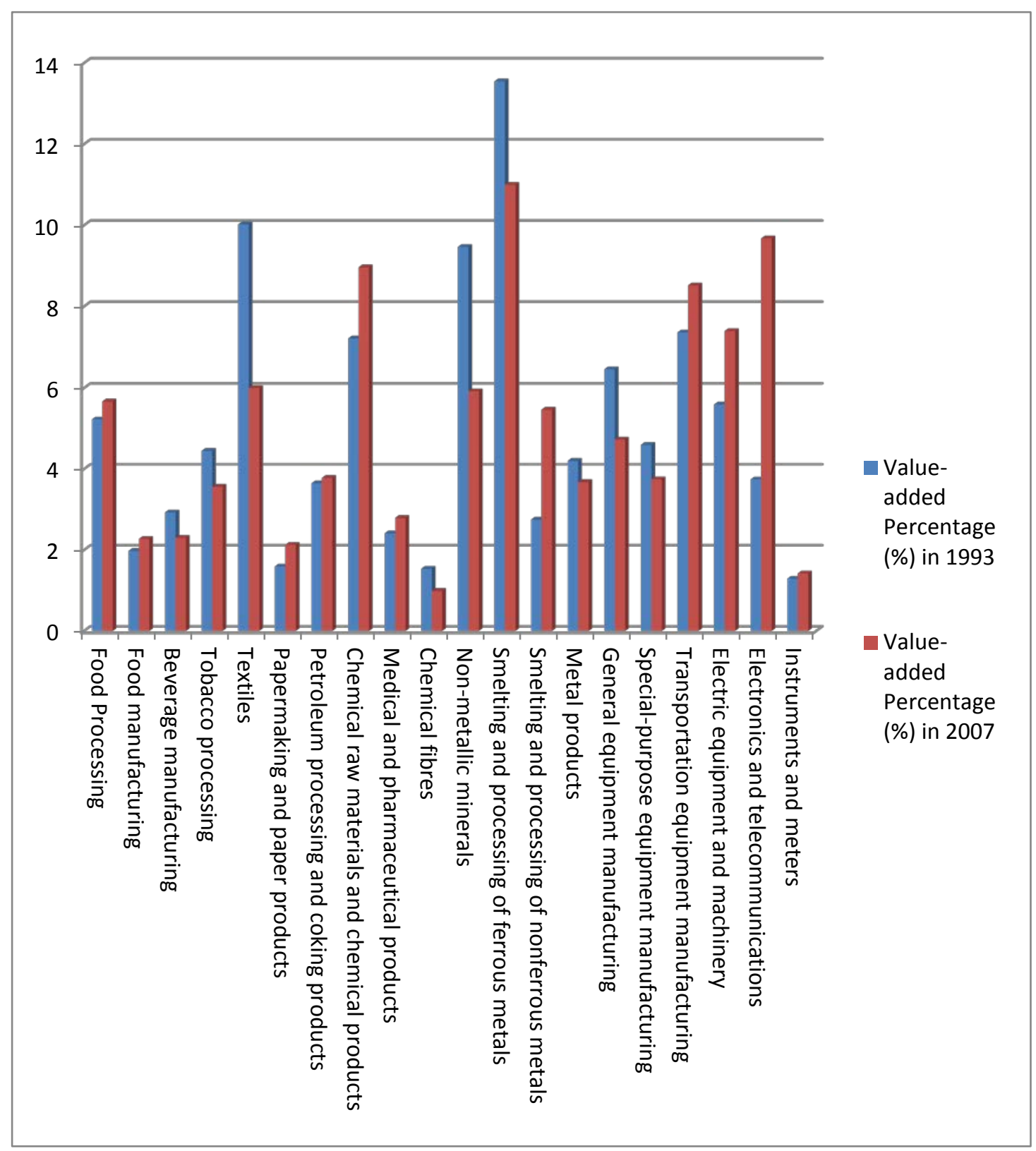

Figure 3 Percentage of value-added for the major industries in 1993 and 2007

Source: Authors' own calculation using data from China Industrial Economic Statistical Yearbook $(1994,2008)$.

China has reached the stage that she needs to rely on industrial upgrading so as to achieve sustainable development in the secondary sector. For that reason, the Chinese government has called for industrial upgrading and many policies are introduced to encourage the low technological-level and low value-added industries to migrate to higher value-added industries. Therefore, it is vital to identify the pattern of inequality in value-added for the different industries. This information can reveal the disparity in industrial upgrading in China and it can aid in the formulation of a comprehensive and coherent strategy in managing inequality while promoting industrial upgrading. However, information on the contribution of each individual industrial sector to the disparity in value-added across the 
provinces is not available in the literature. It is very unfortunately that even though the development of the high value-added industries and its distribution across the provinces are crucial components of the industrialization story in China, but as yet, no decomposition of inequality has been carried out to examine the impacts.

\section{Methods}

Although there are many different indicators for inequality measurement, the most common one is the Gini coefficient. The Gini coefficient has several merits; it satisfies both the Pigou-Dalton condition and the property of income-zero-homogeneity. The Pigou-Dalton principle suggests that if there is a transfer of income from a rich entity to a poor entity, then it should result in a decline of the inequality indicator so long as the transfer does not reverse the ranking of the two in the overall income distribution. The property of income-zero-homogeneity suggests that the value of the inequality measurement should remain unchanged when there is a scalar change of the whole income distribution.

The calculation of Gini coefficient is based on the Lorenz curve, which plots the cumulative share of income against the cumulative share of population from lowest to highest incomes. The Gini coefficient can be calculated as the ratio of the area that lies between the uniform distribution line (that is the 45 degree line of the Lorenz curve) and the Lorenz curve over the total area under the uniform distribution line. The Gini coefficient can be calculated by different formulae. One formula of the population-weighted Gini coefficient is in the form:

$$
\sum_{i} \sum_{j} \frac{\left|y_{i}-y_{j}\right|}{2 \mu} \frac{n_{i}}{N} \frac{n_{j}}{N}
$$

where $y_{i}$ and $y_{j}$ are the income per capita in region $i$ and region $j$ respectively, $n_{i}$ and $n_{j}$ are population in region $i$ and region $j$ respectively, $N$ is total population in all the regions, and $\mu=\sum_{i} \frac{y_{i} n_{i}}{N}$ (Tsui, 1996).

The value of the Gini coefficient ranges from 0 to I. The value of I corresponds to perfect income inequality, while the value of 0 corresponds to perfect income equality. The Gini coefficient can be decomposed into various income sources so as to work out the contribution of each income source 
to total inequality. It is worth noting that there are many different ways to decompose the Gini coefficient, from game theory (Pyatt, 1976) to regression (Lerman and Yitzhaki, 1984, Lerman and Yitzhaki, 1985, Lerman and Yitzhaki, 1989), to matrix calculation (Silber, 1989). However, the approach suggested by Yao (1999) is adopted in this paper because of its simplicity and accuracy.

$$
G=\sum_{s=1}^{S} w_{s} C_{s}
$$

where $G$ is the Gini coefficient, $w_{s}$ is the income share of source $s$ in total income and $C_{s}$ is the concentration coefficients of the income source s. So the overall Gini coefficient can be viewed as a weighted sum of concentration coefficients which can be calculated by:

$$
C_{s}=1-\sum_{j=1}^{m} P_{j}\left(2 Q_{s j}-w_{s j}\right)
$$

where $Q_{s j}=\sum_{l=1}^{j} w_{s l}, P_{j}$ is the population share in total population for region $j, w_{s j}$ is the share of income for region $j$ in total source income $s$. It should be noted that both $w_{s j}$ and $P_{j}$ should be sorted in ascending order of total income per capita in the calculation of $C_{s}$ (for details, interested reader please refer to Yao, 1999).

Based on equations (2) and (3), the contribution of each individual source income can then be calculated as:

Contribution of source income $s=w_{s} C_{s} / G$

\section{Data}

Two databases are used in this study. The first one is a county-level database which is used in decomposition of inequality in terms of GRP per capita by three strata of industries, namely, the primary, secondary and tertiary industries. The analysis result of this database can show the contributions of the three industries to overall inequality amongst the county-level units; therefore, it can reveal the impacts of structural transformation on regional inequality. The other set of data is a provincial level database which is used in decomposition of inequality in terms of value-added per capita by the major industries reported in the China Industrial Economic Statistical Yearbook. The analysis 
result derived from this value-added database can provide information on the impacts of industrial upgrading on regional disparity in industrial development.

It should be noted that the same spatial entities should be used in the calculation of the Gini coefficient for every year, otherwise, the measurement of inequality is not consistent and it cannot be compared across time. For example, if a region which contributes substantially to overall inequality is omitted in a particular year, then the inequality may drop suddenly, and it will give a false impression of a decline in inequality. Therefore, it is required to use the same spatial entities in calculating the Gini coefficient for every year. Because of the unavailability of data in some of the provinces, so the county-level database is compiled from the data of counties and county-level cities in 22 provinces from 1997 to 2010 .

The county-level units in China can be categorized into three administrative groups, namely, the districts, the counties and the county-level cities. However, the data of district is not available for many provinces in the period; therefore, districts are not included in this study. As a result, the municipalities of Beijing, Tianjin, Shanghai and Chongqing are not included in the analysis because most of the county-level units within these municipalities are districts. It should be noted that Chongqing was upgraded to the administrative status of municipality and separated from Sichuan in 1997, given the fact that Chongqing is not included in this study; therefore, 1997 is selected as the beginning year of the database.

The data of population and GRP of the three strata of industries are compiled from the Provincial Statistical Yearbook (State Statistical Bureau, 1998 - 2008a). If the data is not available, then the data from the China Statistical Yearbook for Regional Economy (State Statistical Bureau, 2004 - 2008) and the Provincial Yearbook (State Statistical Bureau, 1998 - 2008b) for each province are used. In order to account for inflation, the GRP of each stratum of industries are deflated by its own provincial sectorspecific deflator individually so as to convert them to 1997 constant prices. However, provincial deflator is used in the process because deflator index for each county-level unit is not available.

One of the thorny issues in the compilation of the county-level database is the change in administrative divisions of the county-level units. As mentioned earlier, it is necessary to use the same spatial entities in measurement for the whole period. From time to time, there are some changes in administrative divisions which can distort the measurement of inequality. For instance, the transfer of control of a wealthy town from a rich county to a poor county may result in a decline in the Gini coefficient. Therefore, some adjustments are necessary so as to make the data comparable across time. The website of Administrative Divisions in China (http://www.xzqh.org) is checked to find out all the changes in administrative divisions for each province for every year. In order to tackle the issue of boundary change, the aggregation approach suggested by Fan (1995) is employed. If there is a 
boundary changes amongst two county-level units, then they are aggregated, so that comparability across time can be maintained. However, since districts are not included in the database, any boundary change which involves districts and another county-level unit will result in the deletion of the data of that particular county-level unit. Similarly, if some of the county-level units upgraded in administrative status and became districts in the study period, then they are deleted from the database. The weakness of the aggregation approach is the underestimation of the level of inequality amongst the aggregated county-level units; however, the changes in administrative divisions are infrequent in the study period. After the procedure of aggregation, the measurement of inequality can be performed comparably across time. It can thus reveal the inequality amongst the county-level units better and would not provide false information when there is a change in administrative divisions.

The per capita value-added database are compiled from the China Industrial Economic Statistical Yearbook (State Statistical Bureau, 1994 - 2008), which provides the figures of value-added of 20 major industries for every province. The database covers the period from 1993 to 2007; however, data is not available from the sources for some of the years. It is worth noting that the value-added data is not available from publication after 2007.

Before 1997, the data of value-added in Chongqing is not available and it is reported as an aggregation with Sichuan, therefore, the data of Chongqing is combined with Sichuan after 1997 to ensure comparability. Both provincial and sector-specific deflators are used together in deflation so as to give a more realistic view of the change in value-added of each industry across time. The overall deflator is calculated as:

Overall deflator $=\sqrt{(\text { provincial deflator })} \times \sqrt{\text { sector specific deflator }}$

\section{Results and discussions}

Table I shows that the Gini coefficient amongst the county-level units in the 22 provinces increased from 0.3418 in 1997 to a maximum of 0.3605 in 2003. After that, the Gini coefficient dropped gradually and was 0.3407 in 2010 . The disparity in secondary industry was found to be the largest contributor to inequality and it accounted for $54.6 \%$ of total regional inequality in 1997. Contribution of the tertiary industry was $31.0 \%$, while the contribution of the primary sector was only $14.4 \%$. The percentage of composition remained more or less stable until 2008. It can be observed that contribution of the secondary industry has declined suddenly since 2009 and was $50.8 \%$ in 2010 . This may reflect the slow growth of manufacturing activities in the coastal areas during the global financial crisis. By contrast, the contribution of the primary sector increased to $17.1 \%$, while the contribution 
of the tertiary sector was $32.1 \%$. However, the disparity in secondary industry amongst the countylevel units was still the crux of the problem of regional inequality in China, it accounted for more than half of the total inequality. In fact, it means that if secondary industry can be distributed perfectly even in China, then the inequality will be cut in half. The disparity in tertiary industry also contributed a lot to total regional inequality; and its contribution was more than 30\% in both 1997 and 2010 . The findings are consistent with earlier studies (Huang et al., 2003, Cheong and Wu, 2013a). Huang et al. (2003) find that secondary industry is the major contributor to inequality, while Cheong and Wu (2013a) show that regional inequality is positively correlated with industrialization and development in the tertiary industry.

Table 1 National Gini coefficient and decomposition by three industries.

$\begin{array}{ccccc}\text { Year } & \begin{array}{c}\text { Gational } \\ \text { Gini }\end{array} & \begin{array}{c}\text { Primary } \\ \text { sector } \%\end{array} & \begin{array}{c}\text { Secondary } \\ \text { sector \% }\end{array} & \begin{array}{c}\text { Tertiary } \\ \text { sector \% }\end{array} \\ 1997 & 0.3418 & 14.4 & 54.6 & 31.0 \\ 1998 & 0.3467 & 14.2 & 54.2 & 31.6 \\ 1999 & 0.3479 & 13.9 & 53.8 & 32.2 \\ 2000 & 0.3526 & 14.5 & 52.9 & 32.6 \\ 2001 & 0.3555 & 14.7 & 52.5 & 32.9 \\ 2002 & 0.3547 & 14.1 & 52.7 & 33.2 \\ 2003 & 0.3605 & 14.2 & 52.9 & 33.0 \\ 2004 & 0.3551 & 13.9 & 53.3 & 32.9 \\ 2005 & 0.3473 & 14.0 & 54.7 & 31.3 \\ 2006 & 0.3483 & 13.8 & 54.7 & 31.5 \\ 2007 & 0.3438 & 14.0 & 54.3 & 31.7 \\ 2008 & 0.3442 & 14.3 & 54.2 & 31.5 \\ 2009 & 0.3430 & 16.1 & 51.6 & 32.3 \\ 2010 & 0.3407 & 17.1 & 50.8 & 32.1\end{array}$

Source: Authors' own calculations.

It should be noted that the findings presented above are based on all the county-level units in 22 provinces and the measurement was made at the national level. However, in order to provide greater details for the analysis, the county-level units can be grouped into different spatial groupings, and measurement can then be carried out for each grouping. In fact, there are three spatial levels for the grouping, namely, the inland-and-coastal, economic zonal and provincial levels.

The inland-and-coastal level has only two constituents at this spatial level, namely, the inland region and the coastal region. In the old three-zone division scheme (which is used by the Chinese government before 2006), the coastal region is the same as the eastern zone, while the inland region consists of the central and western zones. However, the provinces of the eastern zone in the four- 
zone division scheme (which has been adopted by the Chinese government since 2006) are different from those of the coastal region. Basically, the coastal region and the eastern zone in the four-zone division scheme are still very similar to each other and have many provinces in common. But, according to the four-zone division scheme, the coastal region now comprises of all the provinces in the eastern zone and another two provinces, namely, Guangxi and Liaoning. In this study, the coastal region is treated in the same way as the eastern zone, whereas the inland region is defined to comprise all the provinces in the central, western and north-eastern zone. Although the definition of the inland and coastal regions used in this study is slightly different from the official definition used in the past, the results of the analyses can be viewed as a study of the disparity between the eastern zone and the other zones.

The county-level units can also be grouped into economic zones. There are four constituents in this level, namely, the eastern, central, western and north-eastern economic zones. The definition of each of the economic zones is based on the 2006 China Statistical Yearbook (State Statistical Bureau, 2006).

The spatial groupings of the county-level units are:

1. Eastern zone: Hebei, Jiangsu, Zhejiang, Fujian, Guangdong and Hainan. The municipalities of Beijing, Tianjin and Shanghai are excluded in this study. The province of Shandong is not included because of unavailability of data. This zone is also treated as the coastal region.

2. Central zone: Anhui, Jiangxi, Henan, and Hunan. The provinces of Shanxi and Hubei are not included because of unavailability of data. This zone is treated as the inland region.

3. Western zone: Inner Mongolia, Guangxi, Sichuan, Guizhou, Yunnan, Gansu, Qinghai, Ningxia and Xinjiang. The municipality of Chongqing is excluded in this study. The provinces of Shaanxi and Tibet are not included because of unavailability of data. This zone is treated as the inland region.

4. North-eastern zone: Liaoning, Jilin and Heilongjiang. This zone is treated as the inland region.

Finally, the county-level units are then grouped according to provinces. There are 22 constituents in this level. Inequality is measured for each province separately and decomposition of inequality is carried out for each province individually so as to reveal information on the impacts of structural transformation on regional inequality in the greatest details.

Table 2 shows the Gini coefficients of both the coastal and inland regions increased in the period. The inequality in the coastal region was higher than the inland region in 2010. The contributions of the secondary sector in both regions were also very high. It was $56.4 \%$ for the coastal region and $\mathbf{4 6 . 4 \%}$ 
for the inland region in 2010 . The contributions of the tertiary industry were $34.5 \%$ for the coastal region and $29.7 \%$ for the inland region. The contribution of the primary industry was very low for the coastal region, it was only $6.4 \%$ in 1997 and it increased to $9.1 \%$ in 2010 , whereas it was $23.9 \%$ for the inland region in 2010. It can be observed that the contributions of the secondary industry fell in both regions, while the contributions of the other two industries increased for both regions in the period.

Table 2 Coastal and inland regional Gini coefficients and decomposition by three strata of industries.

\begin{tabular}{|c|c|c|c|c|c|}
\hline \multirow[t]{7}{*}{ Region } & Year & Gini & $\begin{array}{l}\text { Primary } \\
\text { sector } \%\end{array}$ & $\begin{array}{c}\text { Secondary } \\
\text { sector } \%\end{array}$ & $\begin{array}{c}\text { Tertiary } \\
\text { sector } \%\end{array}$ \\
\hline & 1997 & 0.3094 & 6.4 & 61.4 & 32.2 \\
\hline & 1998 & 0.3079 & 6.4 & 61.2 & 32.4 \\
\hline & 1999 & 0.3110 & 7.1 & 60.1 & 32.8 \\
\hline & 2000 & 0.3145 & 7.0 & 59.5 & 33.5 \\
\hline & 2001 & 0.3191 & 7.1 & 58.7 & 34.2 \\
\hline & 2002 & 0.3245 & 6.7 & 58.8 & 34.5 \\
\hline \multirow[t]{14}{*}{ Coastal } & 2003 & 0.3325 & 5.8 & 59.7 & 34.5 \\
\hline & 2004 & 0.3336 & 5.7 & 59.6 & 34.7 \\
\hline & 2005 & 0.3464 & 6.3 & 60.9 & 32.8 \\
\hline & 2006 & 0.3505 & 6.2 & 60.8 & 33.1 \\
\hline & 2007 & 0.3532 & 6.3 & 60.5 & 33.2 \\
\hline & 2008 & 0.3520 & 6.4 & 59.8 & 33.8 \\
\hline & 2009 & 0.3474 & 8.2 & 57.2 & 34.6 \\
\hline & 2010 & 0.3403 & 9.1 & 56.4 & 34.5 \\
\hline & 1997 & 0.2880 & 22.1 & 49.0 & 28.9 \\
\hline & 1998 & 0.2908 & 21.2 & 48.5 & 30.3 \\
\hline & 1999 & 0.2903 & 20.0 & 48.8 & 31.2 \\
\hline & 2000 & 0.2973 & 21.2 & 47.8 & 31.0 \\
\hline & 2001 & 0.3003 & 21.4 & 47.3 & 31.3 \\
\hline & 2002 & 0.2977 & 20.9 & 47.5 & 31.6 \\
\hline \multirow[t]{8}{*}{ Inland } & 2003 & 0.3022 & 21.5 & 47.5 & 31.0 \\
\hline & 2004 & 0.2983 & 21.3 & 48.2 & 30.5 \\
\hline & 2005 & 0.2928 & 20.9 & 49.4 & 29.7 \\
\hline & 2006 & 0.2942 & 20.5 & 49.4 & 30.0 \\
\hline & 2007 & 0.2926 & 21.7 & 48.3 & 30.0 \\
\hline & 2008 & 0.2972 & 21.9 & 49.1 & 29.0 \\
\hline & 2009 & 0.3006 & 23.2 & 46.9 & 29.9 \\
\hline & 2010 & 0.3009 & 23.9 & 46.4 & 29.7 \\
\hline
\end{tabular}

Source: Authors' own calculations. 
Table 3 shows that the decomposition results for the four economic zones. The inequalities of the eastern, central and north-eastern economic zones increased in the period, but interestingly, the inequality of the western zone declined from $0.325 \mathrm{I}$ in 1997 to 0.3047 in 2010. It may be due to the 'Campaign to Open up the West' which was launched in 1999 to stimulate economic development in the western provinces (for details of the campaign and its impacts, see Goodman, 2004, and Golley, 2007). However, it can be observed that the contribution of the secondary industry fell in each of the economic zone, while the contributions of the other two industries increased in the same period (except the contribution of the tertiary industry in the central zone which declined from $25.9 \%$ in 1997 to $23.5 \%$ in 2010 ). The contribution of the secondary industry was found to be the largest contributor to regional inequality in all economic zones. In 2010, the contribution of secondary industry in the central was the highest amongst the zones, with a value of $61.3 \%$; the second highest contribution came from the eastern zone, which had a value of $56.4 \%$. The contribution of the northeastern zone was less than half and it was $45.6 \%$, whilst the western zone had the lowest value of only $41.6 \%$. It can thus be concluded that the higher the development level of the economic zone, the higher the contribution of the secondary industry to regional inequality.

Table 3 Economic zonal Gini coefficients and decomposition by three strata of industries.

\begin{tabular}{|c|c|c|c|c|c|}
\hline \multirow[t]{7}{*}{ Zone } & Year & Gini & $\begin{array}{l}\text { Primary } \\
\text { sector } \%\end{array}$ & $\begin{array}{c}\text { Secondary } \\
\text { sector } \%\end{array}$ & $\begin{array}{c}\text { Tertiary } \\
\text { sector } \%\end{array}$ \\
\hline & 1997 & 0.3094 & 6.4 & 61.4 & 32.2 \\
\hline & 1998 & 0.3079 & 6.4 & 61.2 & 32.4 \\
\hline & 1999 & 0.3110 & 7.1 & 60.1 & 32.8 \\
\hline & 2000 & 0.3145 & 7.0 & 59.5 & 33.5 \\
\hline & 2001 & 0.3191 & 7.1 & 58.7 & 34.2 \\
\hline & 2002 & 0.3245 & 6.7 & 58.8 & 34.5 \\
\hline \multirow{13}{*}{ Eastern } & 2003 & 0.3325 & 5.8 & 59.7 & 34.5 \\
\hline & 2004 & 0.3336 & 5.7 & 59.6 & 34.7 \\
\hline & 2005 & 0.3464 & 6.3 & 60.9 & 32.8 \\
\hline & 2006 & 0.3505 & 6.2 & 60.8 & 33.1 \\
\hline & 2007 & 0.3532 & 6.3 & 60.5 & 33.2 \\
\hline & 2008 & 0.3520 & 6.4 & 59.8 & 33.8 \\
\hline & 2009 & 0.3474 & 8.2 & 57.2 & 34.6 \\
\hline & 2010 & 0.3403 & 9.1 & 56.4 & 34.5 \\
\hline & 1997 & 0.2200 & 12.2 & 61.9 & 25.9 \\
\hline & 1998 & 0.2236 & 14.0 & 59.1 & 26.9 \\
\hline & 1999 & 0.2198 & 13.9 & 58.0 & 28.1 \\
\hline & 2000 & 0.2268 & 14.4 & 57.2 & 28.4 \\
\hline & 2001 & 0.2348 & 15.4 & 56.3 & 28.3 \\
\hline
\end{tabular}




\begin{tabular}{cccccc}
\multirow{4}{*}{ Central } & 2002 & 0.2340 & 14.7 & 56.2 & 29.1 \\
& 2003 & 0.2442 & 15.3 & 55.8 & 28.9 \\
& 2004 & 0.2437 & 15.5 & 57.7 & 26.8 \\
& 2005 & 0.2463 & 14.7 & 61.0 & 24.3 \\
& 2006 & 0.2518 & 13.9 & 61.4 & 24.8 \\
& 2007 & 0.2500 & 13.8 & 61.4 & 24.9 \\
& 2008 & 0.2548 & 13.9 & 62.3 & 23.8 \\
& 2009 & 0.2520 & 15.2 & 60.9 & 23.9 \\
& 2010 & 0.2470 & 15.3 & 61.3 & 23.5 \\
& & & & & \\
& 1997 & 0.3251 & 26.0 & 43.6 & 30.4 \\
& 1998 & 0.3156 & 24.4 & 43.6 & 32.0 \\
& 1999 & 0.3153 & 22.6 & 45.2 & 32.3 \\
& 2000 & 0.3207 & 23.2 & 44.7 & 32.1 \\
& 2001 & 0.3243 & 22.8 & 44.6 & 32.5 \\
& 2002 & 0.3222 & 23.2 & 44.4 & 32.4 \\
& 2003 & 0.3208 & 23.4 & 45.5 & 31.1 \\
& 2010 & 0.2662 & 19.9 & 45.6 & 34.5
\end{tabular}

Source: Authors' own calculations. 
The decomposition results of the provincial Gini coefficients are shown in Table 4. However, in order to save space, only the contributions in 1997 and 2010 were presented. Nearly all the results show that the uneven distribution of the secondary sector is the largest contributor to inequality in each province, except Guangxi (1997 and 2007), Ningxia (only in 1997) and Heilongjiang (only in 2010). Undoubtedly, the findings show that the unevenness in industrialization is the root of the problem of regional inequality in China.

For the provinces within the eastern economic zone, the contributions of the secondary sector in Fujian and Guangdong declined considerably in this period. The contribution of secondary sector of Fujian was $59.1 \%$ in 1997 and it dropped to $50.9 \%$ in 2010 , while the contribution of secondary industry in Guangdong declined from $53.7 \%$ in 1997 to $35.1 \%$ in 2010 . However, it is worth noting that regional inequality in these two provinces also dropped considerably in the period. The Gini coefficient of Fujian declined from 0.2704 to 0.2162 , whereas the Gini coefficient of Guangdong declined from 0.2570 to 0.2191 . By contrast, the Gini coefficient of the two relatively less industrialized provinces (Hainan and Hebei) increased with the contribution of the secondary sector. The Gini coefficients of Jiangsu and Zhejiang did not change much and neither did the contribution of the secondary sector in these provinces. 
Table 4 Provincial Gini coefficients and decomposition by three strata of industries.

\begin{tabular}{|c|c|c|c|c|c|c|c|c|c|}
\hline \multirow{3}{*}{ Zone } & & \multirow[b]{2}{*}{$\begin{array}{c}2010 \\
\text { Secondary sector } \\
\%\end{array}$} & \multirow[b]{2}{*}{$\begin{array}{c}\text { Tertiary sector } \\
\%\end{array}$} \\
\hline & Province & $\begin{array}{l}1997 \\
\text { Gini }\end{array}$ & $\begin{array}{c}\text { Primary sector } \\
\%\end{array}$ & $\begin{array}{c}1997 \\
\text { Secondary sector } \\
\%\end{array}$ & $\begin{array}{c}\text { Tertiary sector } \\
\%\end{array}$ & $\begin{array}{l}2010 \\
\text { Gini }\end{array}$ & $\begin{array}{c}\text { Primary sector } \\
\%\end{array}$ & & \\
\hline & Fujian & 0.2704 & 4.7 & 59.1 & 36.1 & 0.2162 & 13.0 & 50.9 & 36.0 \\
\hline \multirow{5}{*}{ Eastern } & Guangdong & 0.2570 & 14.8 & 53.7 & 31.5 & 0.2191 & 31.8 & 35.1 & 33.1 \\
\hline & Hainan & 0.1558 & 30.8 & 35.9 & 33.3 & 0.1603 & 18.9 & 48.0 & 33.2 \\
\hline & Hebei & 0.2297 & 15.4 & 54.8 & 29.7 & 0.2905 & 11.8 & 58.2 & 30.0 \\
\hline & Jiangsu & 0.3899 & 1.9 & 61.2 & 36.9 & 0.3913 & 0.8 & 59.1 & 40.1 \\
\hline & Zhejiang & 0.2302 & 9.2 & 65.0 & 25.8 & 0.2394 & 13.7 & 56.0 & 30.4 \\
\hline \multirow{4}{*}{ Central } & Anhui & 0.1949 & 13.4 & 57.3 & 29.2 & 0.1962 & 24.2 & 50.0 & 25.8 \\
\hline & Henan & 0.2628 & 4.9 & 69.9 & 25.2 & 0.2389 & 1.6 & 74.9 & 23.5 \\
\hline & Hunan & 0.1752 & 23.2 & 52.3 & 24.5 & 0.2642 & 24.3 & 52.4 & 23.3 \\
\hline & Jiangxi & 0.1627 & 26.1 & 45.6 & 28.4 & 0.2138 & 29.0 & 43.7 & 27.3 \\
\hline \multirow{9}{*}{ Western } & Gansu & 0.3640 & 34.2 & 45.0 & 20.8 & 0.3609 & 26.0 & 50.5 & 23.5 \\
\hline & Guangxi & 0.2038 & 36.3 & 35.8 & 27.8 & 0.1994 & 46.7 & 31.6 & 21.7 \\
\hline & Guizhou & 0.2263 & 18.3 & 58.8 & 22.9 & 0.1875 & 6.5 & 61.6 & 31.9 \\
\hline & Inner Mongolia & 0.2634 & 24.9 & 46.3 & 28.8 & 0.3556 & 13.7 & 46.0 & 40.4 \\
\hline & Ningxia & 0.3943 & 38.5 & 37.6 & 23.9 & 0.3065 & 23.8 & 48.9 & 27.3 \\
\hline & Qinghai & 0.2905 & 17.8 & 51.5 & 30.7 & 0.3327 & 17.5 & 56.5 & 26.1 \\
\hline & Sichuan & 0.2870 & 11.4 & 54.2 & 34.4 & 0.2272 & 18.1 & 43.3 & 38.7 \\
\hline & Xinjiang & 0.3306 & 27.7 & 43.4 & 29.0 & 0.3747 & 33.6 & 40.3 & 26.1 \\
\hline & Yunnan & 0.3359 & 20.8 & 47.7 & 31.4 & 0.2830 & 20.9 & 47.2 & 31.9 \\
\hline \multirow{3}{*}{$\begin{array}{l}\text { North- } \\
\text { eastern }\end{array}$} & Heilongjiang & 0.1858 & 31.5 & 35.0 & 33.5 & 0.2750 & 44.1 & 23.0 & 33.0 \\
\hline & Jilin & 0.1490 & 11.2 & 47.3 & 41.4 & 0.1441 & 36.8 & 38.8 & 24.3 \\
\hline & Liaoning & 0.3254 & 14.4 & 58.0 & 27.6 & 0.2451 & 11.7 & 54.5 & 33.8 \\
\hline
\end{tabular}

Source: Authors' own calculations. 
However, for the provinces in the central and western economic zones, the picture is a little bit blurred. Although it can be observed that contribution of the secondary sector exhibited a positive influence on regional inequality for many provinces, some provinces did not follow this rule and they registered an increase (decline) in regional inequality with a decline (increase) in contribution of the secondary sector. However, some of them can be explained by the development in the tertiary sector, for example, the contribution of the secondary sector in Inner Mongolia dropped from 46.3\% to $46.0 \%$ in the period but the regional inequality increased from 0.2634 to 0.3556 . But it can be observed that the contribution of the tertiary sector in Inner Mongolia increased from $28.8 \%$ to $40.4 \%$, while the contribution of the primary sector declined from $24.9 \%$ to only $13.7 \%$. However, it should be noted that there are some provinces whose regional inequality cannot be explained solely by the changes in contributions of the secondary and tertiary sectors.

For the provinces in the north-eastern zone, it can be observed that both Jilin and Liaoning had a fall in regional inequality and also a decline in the contribution of secondary industry. However, Heilongjiang is quite different, the regional inequality increased with a decline in the non-agricultural sector.

Cheong and $\mathrm{Wu}(2012)$ show that the administrative status of the county-level unit can greatly affect regional inequality. City and county have different transitional dynamics and thus they exert different impacts on inequality. In order to investigate the impacts of structural transform on regional inequality in greater details, the county-level database was divided into two smaller databases. One of them is made up of cities only, while the other is made up of counties only. The analytical results of these two subgroups can reveal the difference between them and the findings are shown in Table 5.

Table 5 National Gini coefficients for the county and city subgroups and decomposition by three strata of industries.

City

$\begin{array}{ccccccc}\text { Year } & \text { Gini } & \begin{array}{c}\text { Primary } \\ \text { sector } \%\end{array} & \begin{array}{c}\text { Secondary } \\ \text { sector } \%\end{array} & \begin{array}{c}\text { Tertiary } \\ \text { sector } \%\end{array} & \text { Gini } & \begin{array}{c}\text { Primary } \\ \text { sector \% }\end{array} \\ 1997 & 0.3185 & 5.6 & 61.5 & 32.9 & 0.2826 & 24.8 \\ 1998 & 0.3234 & 5.9 & 61.0 & 33.1 & 0.2856 & 24.3 \\ 1999 & 0.3225 & 5.8 & 60.3 & 33.9 & 0.2881 & 23.8 \\ 2000 & 0.3281 & 6.0 & 59.6 & 34.3 & 0.2929 & 24.5 \\ 2001 & 0.3289 & 5.9 & 59.3 & 34.8 & 0.2966 & 24.7 \\ 2002 & 0.3321 & 5.6 & 59.5 & 35 & 0.2933 & 24.3 \\ 2003 & 0.3403 & 5.3 & 60.1 & 34.6 & 0.2974 & 24.5 \\ 2004 & 0.3382 & 4.9 & 60.2 & 34.9 & 0.2931 & 24.5 \\ 2005 & 0.3445 & 4.1 & 62.7 & 33.2 & 0.2849 & 25 \\ 2006 & 0.3495 & 3.9 & 62.3 & 33.8 & 0.2852 & 24.9 \\ 2007 & 0.3486 & 3.9 & 61.7 & 34.3 & 0.2821 & 25.3 \\ 2008 & 0.3493 & 4.2 & 60.8 & 34.9 & 0.2851 & 25.5 \\ 2009 & 0.3457 & 5.9 & 58.4 & 35.6 & 0.2852 & 27.5 \\ 2010 & 0.3435 & 6.9 & 57.5 & 35.6 & 0.2845 & 28.9\end{array}$

County

Secondary Tertiary sector $\%$ sector $\%$

$47.5 \quad 27.6$

$47.4 \quad 28.3$

$47.4 \quad 28.8$

$46.5 \quad 29$

$46.1 \quad 29.2$

$46.2 \quad 29.6$

$46.3 \quad 29.2$

$46.8 \quad 28.7$

$47.5 \quad 27.5$

$47.9 \quad 27.2$

$47.7 \quad 27$

$48.1 \quad 26.4$

$45.2 \quad 27.2$

$44.3 \quad 26.8$

Source: Authors' own calculations. 
It is shown that the Gini coefficient of the city subgroup was much higher than the county subgroup. Moreover, the contributions of the secondary and tertiary sectors in the city subgroup were higher than those in the county subgroup for all the years. In 2010, the contribution of the secondary industry was $57.5 \%$ for the cities, while it was $44.3 \%$ for the counties. The contribution of the primary industry was $28.9 \%$ for the counties, whereas it was only $6.9 \%$ for the cities. However, both the city and county subgroups show a decline in the contribution of secondary sector across the years of study.

Based on the findings presented above, it can be concluded that, undoubtedly, industrialization was the main driver of inequality amongst the county-level units. However, development in tertiary sector also played a role in inequality, but its effect is not as significant as the secondary sector. This rule applies to all spatial groups aggregated at the national, inland-and-coastal, and economic zonal levels. It also applies to most of the provinces but there are some exceptions found. It is a very encouraging finding because it means that although inequality will most likely increase in the process of industrialization, however, the impacts on inequality can be lessened or even reversed through proper planning. Structural transformation such as the development in the secondary and tertiary industries can boost the output of poor regions considerably. In fact, inequality can be reduced if industrialization is targeted specifically at the underdeveloped regions, while it will be exacerbated further if industrialization is targeted at the affluent regions. Therefore, it calls for proper planning in industrialization policy, especially for those provinces which exhibit a high percentage in contribution of the secondary sector. Primary focus should be given to the cities as it is shown earlier that their contribution of secondary sector to inequality was much higher than the counties.

\section{Further Analysis}

The previous section shows that the uneven distribution in industrialization is the major force which shapes the regional inequality in China. Therefore, it is crucial to investigate industrialization further so that pragmatic suggestions can be put forward for policy formulation. It is thus better to break the secondary sector down into several major industries and then study the contribution of each industry individually. In this section, a database of value-added of the major industries is employed. The use of value-added in the analysis not only can show the unevenness in distribution of the different industries amongst the provinces, but it can also reveal the relationship between industrial upgrading and regional inequality. 
Table 6 shows the decomposition results of the inequality in value-added per capita by the major industries as listed in the China Industrial Economic Statistical Yearbook (State Statistical Bureau, 1994 2008). It can be observed that the Gini coefficient of value-added increased from 0.3423 in 1993 to 0.4003 in 2007. It means that the distribution of the major industries has become more and more uneven in the study period.

It should be noted that $\mathrm{SI}$ to $\mathrm{S} 4$ are food and tobacco industries, the total contribution of these industries was $6.04 \%$ in 1993 and it fell to $5.29 \%$ in 2007 . For the textiles industry, its contribution dropped significantly from $12.92 \%$ down to only $6.65 \%$ in that period. However, the contribution of the papermaking and paper products industry increased from $1.20 \%$ to $2.13 \%$, though overall contribution was still very small. 


\section{Table 6 Decomposition of inequality in value-added by major industrial sectors}

\begin{tabular}{|c|c|c|c|c|c|c|c|c|c|c|c|c|c|c|c|c|c|c|c|c|c|}
\hline ear & Gini & S1 & S2 & S3 & S4 & S5 & S6 & S7 & S8 & S9 & S10 & S11 & S12 & S13 & S14 & S15 & S16 & S17 & S18 & S19 & $S \angle C$ \\
\hline 1993 & 0.3423 & 2.52 & 1.76 & 1.62 & 0.14 & 12.92 & 1.20 & 4.55 & 7.68 & 2.45 & 2.68 & 6.20 & 14.21 & 0.91 & 5.35 & 7.34 & 4.93 & 8.57 & 7.49 & 5.59 & 1.88 \\
\hline 994 & .3418 & 1.32 & 1.71 & 1.87 & 1.89 & 12.10 & 1.32 & 4.32 & 7.30 & 2.32 & 2.81 & 6.40 & 12.31 & 0.93 & 5.11 & 7.51 & 5.37 & 8.66 & 7.52 & 7.14 & .09 \\
\hline 95 & 0.3575 & 2.11 & 1.91 & 1.69 & 1.82 & 10.47 & 1.31 & 5.35 & 8.09 & 1.91 & 3.11 & 6.21 & 9.69 & 0.66 & 4.75 & 7.82 & 4.66 & 8.74 & 7.87 & 9.95 & \\
\hline 97 & 0.3362 & 2.41 & 2.61 & 2.34 & 0.70 & 10.00 & 1.89 & 3.51 & 8.18 & 2.83 & 2.41 & 5.55 & 7.38 & 0.11 & 5.08 & 7.92 & 4.76 & 8.85 & 9.80 & 11.68 & \\
\hline 99 & 0.4006 & 2.99 & 2.15 & 2.10 & 0.76 & 8.38 & 2.28 & 2.52 & 7.95 & 2.84 & 2.50 & 5.91 & 5.64 & 0.43 & 5.53 & 6.40 & 3.80 & 8.58 & 10.91 & 16.17 & .15 \\
\hline 2000 & 0.3929 & 2.57 & 2.15 & 1.83 & 0.84 & 8.14 & 2.19 & 2.26 & 8.40 & 2.68 & 2.65 & 5.46 & 5.68 & 0.17 & 5.23 & 6.36 & 3.91 & 7.56 & 11.49 & 18.31 & .13 \\
\hline 01 & .4037 & 2.53 & 1.92 & 1.78 & 1.26 & 8.22 & 2.31 & 2.18 & 8.72 & 2.79 & 1.57 & 5.27 & 5.62 & 0.38 & 5.25 & 6.73 & 3.82 & 8.28 & 11.91 & 17.46 & .00 \\
\hline 02 & 4105 & 2.58 & 1.72 & 1.60 & 1.91 & 7.87 & 2.44 & 1.99 & 8.41 & 2.88 & 1.45 & 4.81 & 5.41 & 0.38 & 5.31 & 6.62 & 3.75 & 9.72 & 11.30 & 18.05 & .80 \\
\hline 003 & 0.4280 & 2.46 & 1.53 & 1.37 & 1.61 & 7.17 & 2.17 & 1.57 & 8.35 & 2.73 & 1.43 & 4.48 & 6.56 & 0.55 & 4.66 & 6.98 & 3.28 & 10.37 & 10.84 & 19.46 & .41 \\
\hline 05 & 0.4254 & 2.62 & 1.65 & 1.08 & 0.30 & 7.21 & 2.15 & 1.38 & 7.96 & 2.32 & 1.21 & 4.78 & 7.75 & 0.72 & 4.66 & 5.69 & 3.57 & 8.00 & 11.61 & 22.81 & 51 \\
\hline 06 & 0.4227 & 2.64 & 1.54 & 0.83 & 0.37 & 6.82 & 2.12 & 1.06 & 7.95 & 2.11 & 1.20 & 4.71 & 7.87 & 0.81 & 4.73 & 6.51 & 3.65 & 7.99 & 11.58 & 22.89 & 6 \\
\hline 07 & 0.4003 & .76 & .52 & 0.77 & 0.24 & 6.65 & 2.13 & 1.04 & 8.54 & 2.14 & 1.31 & 5.07 & 6.95 & 0.76 & 5.09 & 7.12 & 3.85 & 9.16 & 11.82 & 20.59 & \\
\hline
\end{tabular}

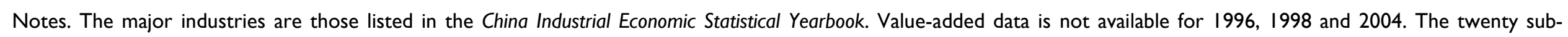

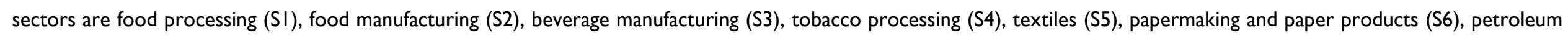

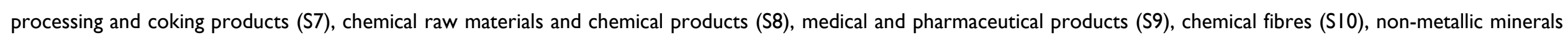

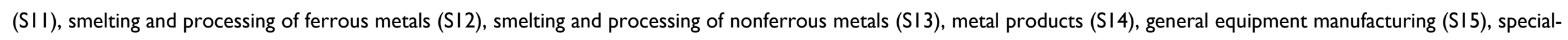

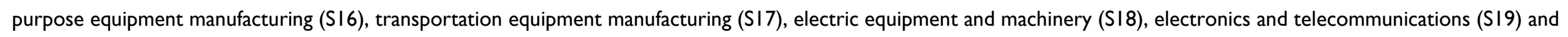
instruments and meters (S20). 
The contributions of most of the heavy industries (from S7 to S16) declined in the period, with the exception of the chemical raw materials and chemical products industry. In contrast, the contributions of the high value-added sectors, namely, transportation equipment manufacturing, electric equipment and machinery, electronics and telecommunications, and instruments and meters industries all registered an increase in that period. The increase in the contribution of the electronics and telecommunications sector was huge. It was only $5.59 \%$ in 1993, but then it increased to $20.59 \%$ in 2007 , with a $268 \%$ increase in contribution. The contribution of the electronics and telecommunications sector has become the largest contributor to inequality in value-added. The contribution of the transportation equipment manufacturing was also very high, and it was $9.16 \%$ in 2007. Similarly, the contribution of the electric equipment and machinery sector was huge and it was $11.82 \%$. However, the contribution of the instruments and meters sector was low and it was only $2.49 \%$. The total contribution of these high value-added industries increased from $23.53 \%$ in 1993 to an alarming level of $44.06 \%$ in 2007.

The provinces have to go through industrial upgrading toward high value-added industrial sectors so as to achieve sustainable development, however, the results show that the process of industrial upgrading was not implemented evenly across the regions. In fact, the high value-added sectors contributed enormously to the disparity in industrial development. Therefore, government should formulate policy to divert the investment flow of the high value-added industries to the underdeveloped regions and ensure that the benefits can spread to the poor provinces.

\section{Conclusions}

It is evident that industrialization and development in tertiary industry both prove beneficial to economic development in China. The surplus labour in the rural areas has been reallocated to the secondary and tertiary sectors. In this process of transformation, not only the living standards of people have improved, but it has also helped boost economic growth in China. But, unfortunately, regional inequality has also increased considerably in this process.

Based on a county-level database, regional inequality is decomposed by the three strata of industries. Decompositions are carried out for different spatial groupings which are aggregated at the national, inland-and-coastal, economic zones. They all show that industrialization is the largest contributor to regional inequality at all the spatial levels. However, some exceptions do appear in the provincial level. It can be concluded that the root of the inequality problem in China is the unevenness in the 
distribution of industrialization. In fact, if industrialization could be distributed perfectly even in China, national inequality can be lowered by half.

The second part of the study focuses on the distribution of the major industries and evaluates its impacts on inequality. The analytical results show that the unevenness in the distribution of the high value-added industries is the major contributor to the disparity in industrialization. Together, the high value-added industries contributed $44.06 \%$ to overall inequality. China needs to rely on industrial upgrading in order to achieve sustainable development, but the findings show that industrial upgrading was not carried out evenly in all the provinces. For example, the contribution of the electronics and telecommunications sector to inequality increased from $5.59 \%$ in 1993 to $20.59 \%$ in 2007.

Industrialization is vital to economic growth; however, the unevenness in the distribution of industrialization can exacerbate regional disparity greatly. Policies should thus be formulated to divert future industrial investment, especially those of the high value-added industries, to the underdeveloped regions. The government should also adopt a comprehensive and coherent strategy in managing inequality while promoting structural transformation and industrial upgrading. 


\section{References}

ACEMOGLU, D. \& ROBINSON, J. A. 200I. A Theory of Political Transitions. American Economic Review, 91, 938 - 963.

ALESINA, A. \& PEROTTI, R. 1996. Income Distribution, Political Instability, and Investment. European Economic Review, 40, 1203 - 1228.

CHEONG, T. S. 2012a. New Evidence of Regional Inequality. In: WU, Y. (ed.) Regional Development and Economic Growth in China. Singapore: World Scientific Publishing.

CHEONG, T. S. 2012b. Trends, Determinants and Consequences of Regional Inequality in China: New Evidence. Doctoral dissertation, University of Western Australia.

CHEONG, T. S. \& WU, Y. 2012. Regional Disparity, Transitional Dynamics and Convergence in China. Unpublished manuscript.

CHEONG, T. S. \& WU, Y. 20I3a. Globalization and Regional Inequality in China. University of Western Australia Business School Discussion Paper, 13.10.

CHEONG, T. S. \& WU, Y. 20I3b. Inequality and Crime Rates in China. University of Western Australia Business School Discussion Paper, I3.II.

DOLLAR, D. 2007. Poverty, Inequality, and Social Disparities During China's Economic Reform. World Bank Policy Research Working Paper No. 4253.

DUTT, P. \& MITRA, D. 2008. Inequality and the Instability of Polity and Policy. Economic Journal, II8, $1285-13 \mid 4$

FAN, C. C. 1995. Of Belts and Ladders: State Policy and Uneven Regional Development in Post-Mao China. Annals of the Association of American Geographers, 85, 421 - 449.

GOH, C.-C., LUO, X. \& ZHU, N. 2009. Income Growth, Inequality and Poverty Reduction: A Case Study of Eight Provinces in China. China Economic Review, 20, 485 - 496.

GOLLEY, J. 2002. Regional Patterns of Industrial Development during China's Economic Transition. Economics of Transition, 10, 761 - 801.

GOLLEY, J. 2007. China's Western Development Strategy and Nature versus Nurture. Journal of Chinese Economic and Business Studies, 5, 115 - 129.

GOODMAN, D. S. G. 2004. The Campaign to "Open Up the West": National, Provincial-Level and Local Perspectives. The China Quarterly, 178, 317 - 334.

HUANG, J.-T., KUO, C.-C. \& KAO, A.-P. 2003. The Inequality of Regional Economic Development in China between I99I and 200I. Journal of Chinese Economic and Business Studies, I, 273 - 285.

HUNG, H.-F. \& KUCINSKAS, J. 20I I. Globalization and Global Inequality: Assessing the Impact of the Rise of China and India, 1980 - 2005. American Journal of Sociology, II6, I478 - I5I3.

KANBUR, R. \& ZHANG, X. 2005. Fifty Years of Regional Inequality in China: a Journey Through Central Planning, Reform, and Openness. Review of Development Economics, 9, 87 - 106.

KUZNETS, S. 1955. Economic Growth and Income Inequality. American Economic Review, 45, I - 28. 
LERMAN, R. I. \& YITZHAKI, S. 1984. A Note on the Calculation and Interpretation of the Gini Index. Economics Letters, 19, $363-368$.

LERMAN, R. I. \& YITZHAKI, S. 1985. Income Inequality Effects by Income Source: A New Approach and Appliations to the United States. Review of Economics and Statistics, 67, I5I - 156.

LERMAN, R. I. \& YITZHAKI, S. 1989. Improving the Accuracy of Estimates of Gini Coefficients. Journal of Econometrics, 42, 43 - 47.

MULLER, E. N. \& SELIGSON, M. A. 1987. Inequality and Insurgency. American Political Science Review, $81,425-452$.

PRADHAN, R. P. 2009. Causal Nexus between Globalization and Income Inequality: An Empirical Study in China. Banking and Finance Letters, I, I4I - I50.

PYATT, G. 1976. On the Interpretation and Disaggregation of Gini Coefficients. Economic Journal, 86, $243-255$

ROZELLE, S. 1994. Rural Industrialization and Increasing Inequality: Emerging Patterns in China's Reforming Economy. Journal of Comparative Economics, 19, 362 - 391.

ROZELLE, S. 1996. Stagnation Without Equity: Patterns of Growth and Inequality in China's Rural Economy. The China Journal, 35, 63 - 92.

SAARI, M. Y. 2007. The Economic Impact of China's Industrialisation on ASEAN: an Inter-Regional Approach. Malaysian Journal of Economic Studies, 44, 5 I - 65.

SILBER, J. 1989. Factor Components, Population Subgroups and the Computation of the Gini Index of Inequality. Review of Economics and Statistics, 7I, 107 - II5.

STATE STATISTICAL BUREAU 1994 - 2008. China Industrial Economic Statistical Yearbook, Beijing, China Statistics Press.

STATE STATISTICAL BUREAU 1998 - 2008a. Provincial Statistical Yearbook, Beijing, China Statistics Press.

STATE STATISTICAL BUREAU 1998 - 2008b. Provincial Yearbook, Beijing, China Statistics Press.

STATE STATISTICAL BUREAU 2004 - 2008. China Statistical Yearbook for Regional Economy, Beijing, China Statistics Press.

STATE STATISTICAL BUREAU 2006. China Statistical Yearbook, Beijing, China Statistics Press.

STATE STATISTICAL BUREAU 20I2. China Statistical Yearbook, Beijing, China Statistics Press.

TSUI, K.-Y. 2007. Forces Shaping China's Interprovincial Inequality. Review of Income and Wealth, 53, $60-92$

TSUI, K. Y. 1996. Economic Reform and Interprovincial Inequality in China. Journal of Development Economics, 50, 353 - 368.

WAN, G. 2004. Accounting for Income Inequality in Rural China: A Regression-Based Approach. Journal of Comparative Economics, 32, 348 - 363.

WANG, S. \& HU, A. 1999. The Political Economy of Uneven Development: The Case of China New York, M. E. Sharpe. 
WEN, D. J. 2007. Too Much Growth, Too Little Development: The Reality behind China's Economic Miracle. Development: China, 50, 30 - 35.

WILKINSON, R. G. \& PICKETT, K. E. 2009. Income Inequality and Social Dysfunction. Annual Review of Sociology, 35, 493 - 511 .

YANG, D. T. 2002. What Has Caused Regional Inequality in China? China Economic Review, I3, 33 I 334.

YAO, S. 1997. Industrialization and Spatial Income Inequality in Rural China, 1986-92. Economics of Transition, 5, 97 - II2.

YAO, S. 1999. On the Decomposition of Gini Coefficients by Population Class and Income Source: a Spreadsheet Approach and Application. Applied Economics, 31, 1249 - 1264.

YU, M. 2012. Industrial Structural Upgrading and Poverty Reduction in China. The Untold Story: Structural Change for Poverty Reduction: The Case of the BRICS. Beijing: Peking University.

ZHANG, Z. 1999. Rural Industrialization in China: From Backyard Furnaces to Township and Village Enterprises. East Asia : An International Quarterly, 17, 61 - 87.

ZHUANG, J. 2008. Inclusive Growth toward a Harmonious Society in the People's Republic of China: Policy Implications. Asian Development Review, 25, 22 - 33. 
Editor, UWA Economics Discussion Papers:

Ernst Juerg Weber

Business School - Economics

University of Western Australia

35 Sterling Hwy

Crawley WA 6009

Australia

Email: ecoadmin@biz.uwa.edu.au

The Economics Discussion Papers are available at:

1980 - 2002: http://ecompapers.biz.uwa.edu.au/paper/PDF\%20of\%20Discussion\%20Papers/

Since 2001: http://ideas.repec.org/s/uwa/wpaper1.html

Since 2004: $\quad$ http://www.business.uwa.edu.au/school/disciplines/economics

\begin{tabular}{|c|c|c|}
\hline \multicolumn{3}{|c|}{$\begin{array}{l}\text { ECONOMICS DISCUSSION PAPERS } \\
2012\end{array}$} \\
\hline $\begin{array}{l}\text { DP } \\
\text { NUMBER }\end{array}$ & AUTHORS & TITLE \\
\hline 12.01 & $\begin{array}{l}\text { Clements, K.W., Gao, G., and } \\
\text { Simpson, T. }\end{array}$ & $\begin{array}{l}\text { DISPARITIES IN INCOMES AND PRICES } \\
\text { INTERNATIONALLY }\end{array}$ \\
\hline 12.02 & Tyers, R. & $\begin{array}{l}\text { THE RISE AND ROBUSTNESS OF ECONOMIC FREEDOM } \\
\text { IN CHINA }\end{array}$ \\
\hline 12.03 & Golley, J. and Tyers, R. & $\begin{array}{l}\text { DEMOGRAPHIC DIVIDENDS, DEPENDENCIES AND } \\
\text { ECONOMIC GROWTH IN CHINA AND INDIA }\end{array}$ \\
\hline 12.04 & Tyers, R. & LOOKING INWARD FOR GROWTH \\
\hline 12.05 & Knight, K. and McLure, M. & THE ELUSIVE ARTHUR PIGOU \\
\hline 12.06 & McLure, M. & $\begin{array}{l}\text { ONE HUNDRED YEARS FROM TODAY: A. C. PIGOU'S } \\
\text { WEALTH AND WELFARE }\end{array}$ \\
\hline 12.07 & Khuu, A. and Weber, E.J. & HOW AUSTRALIAN FARMERS DEAL WITH RISK \\
\hline 12.08 & Chen, M. and Clements, K.W. & PATTERNS IN WORLD METALS PRICES \\
\hline 12.09 & Clements, K.W. & UWA ECONOMICS HONOURS \\
\hline 12.10 & Golley, J. and Tyers, R. & $\begin{array}{l}\text { CHINA'S GENDER IMBALANCE AND ITS ECONOMIC } \\
\text { PERFORMANCE }\end{array}$ \\
\hline 12.11 & Weber, E.J. & $\begin{array}{l}\text { AUSTRALIAN FISCAL POLICY IN THE AFTERMATH OF } \\
\text { THE GLOBAL FINANCIAL CRISIS }\end{array}$ \\
\hline 12.12 & Hartley, P.R. and Medlock III, K.B. & $\begin{array}{l}\text { CHANGES IN THE OPERATIONAL EFFICIENCY OF } \\
\text { NATIONAL OIL COMPANIES }\end{array}$ \\
\hline 12.13 & $\mathrm{Li}, \mathrm{L}$. & $\begin{array}{l}\text { HOW MUCH ARE RESOURCE PROJECTS WORTH? A } \\
\text { CAPITAL MARKET PERSPECTIVE }\end{array}$ \\
\hline 12.14 & Chen, A. and Groenewold, N. & $\begin{array}{l}\text { THE REGIONAL ECONOMIC EFFECTS OF A } \\
\text { REDUCTION IN CARBON EMISSIONS AND AN } \\
\text { EVALUATION OF OFFSETTING POLICIES IN CHINA }\end{array}$ \\
\hline 12.15 & Collins, J., Baer, B. and Weber, E.J. & $\begin{array}{l}\text { SEXUAL SELECTION, CONSPICUOUS CONSUMPTION } \\
\text { AND ECONOMIC GROWTH }\end{array}$ \\
\hline
\end{tabular}




\begin{tabular}{|c|c|c|}
\hline 12.16 & $\mathrm{Wu}, \mathrm{Y}$. & TRENDS AND PROSPECTS IN CHINA'S R\&D SECTOR \\
\hline 12.17 & Cheong, T.S. and Wu, Y. & $\begin{array}{l}\text { INTRA-PROVINCIAL INEQUALITY IN CHINA: AN } \\
\text { ANALYSIS OF COUNTY-LEVEL DATA }\end{array}$ \\
\hline 12.18 & Cheong, T.S. & THE PATTERNS OF REGIONAL INEQUALITY IN CHINA \\
\hline 12.19 & $\mathrm{Wu}, \mathrm{Y}$. & $\begin{array}{l}\text { ELECTRICITY MARKET INTEGRATION: GLOBAL } \\
\text { TRENDS AND IMPLICATIONS FOR THE EAS REGION }\end{array}$ \\
\hline 12.20 & Knight, K. & $\begin{array}{l}\text { EXEGESIS OF DIGITAL TEXT FROM THE HISTORY OF } \\
\text { ECONOMIC THOUGHT: A COMPARATIVE } \\
\text { EXPLORATORY TEST }\end{array}$ \\
\hline 12.21 & Chatterjee, I. & $\begin{array}{l}\text { COSTLY REPORTING, EX-POST MONITORING, AND } \\
\text { COMMERCIAL PIRACY: A GAME THEORETIC } \\
\text { ANALYSIS }\end{array}$ \\
\hline 12.22 & Pen, S.E. & QUALITY-CONSTANT ILLICIT DRUG PRICES \\
\hline 12.23 & Cheong, T.S. and Wu, Y. & $\begin{array}{l}\text { REGIONAL DISPARITY, TRANSITIONAL DYNAMICS } \\
\text { AND CONVERGENCE IN CHINA }\end{array}$ \\
\hline 12.24 & Ezzati, P. & $\begin{array}{l}\text { FINANCIAL MARKETS INTEGRATION OF IRAN } \\
\text { WITHIN THE MIDDLE EAST AND WITH THE REST OF } \\
\text { THE WORLD }\end{array}$ \\
\hline 12.25 & Kwan, F., Wu, Y. and Zhuo, S. & $\begin{array}{l}\text { RE-EXAMINATION OF THE SURPLUS AGRICULTURAL } \\
\text { LABOUR IN CHINA }\end{array}$ \\
\hline 12.26 & $\mathrm{Wu}, \mathrm{Y}$. & R\&D BEHAVIOUR IN CHINESE FIRMS \\
\hline 12.27 & Tang, S.H.K. and Yung, L.C.W. & $\begin{array}{l}\text { MAIDS OR MENTORS? THE EFFECTS OF LIVE-IN } \\
\text { FOREIGN DOMESTIC WORKERS ON SCHOOL } \\
\text { CHILDREN'S EDUCATIONAL ACHIEVEMENT IN HONG } \\
\text { KONG }\end{array}$ \\
\hline 12.28 & Groenewold, N. & $\begin{array}{l}\text { AUSTRALIA AND THE GFC: SAVED BY ASTUTE } \\
\text { FISCAL POLICY? }\end{array}$ \\
\hline
\end{tabular}




\section{ECONOMICS DISCUSSION PAPERS}

2013

\begin{tabular}{|c|c|c|}
\hline $\begin{array}{l}\text { DP } \\
\text { NUMBER }\end{array}$ & AUTHORS & TITLE \\
\hline 13.01 & $\begin{array}{l}\text { Chen, M., Clements, K.W. and } \\
\text { Gao, G. }\end{array}$ & THREE FACTS ABOUT WORLD METAL PRICES \\
\hline 13.02 & Collins, J. and Richards, O. & $\begin{array}{l}\text { EVOLUTION, FERTILITY AND THE AGEING } \\
\text { POPULATION }\end{array}$ \\
\hline 13.03 & $\begin{array}{l}\text { Clements, K., Genberg, H., } \\
\text { Harberger, A., Lothian, J., } \\
\text { Mundell, R., Sonnenschein, H. and } \\
\text { Tolley, G. }\end{array}$ & LARRY SJAASTAD, 1934-2012 \\
\hline 13.04 & Robitaille, M.C. and Chatterjee, I. & MOTHERS-IN-LAW AND SON PREFERENCE IN INDIA \\
\hline 13.05 & Clements, K.W. and Izan, I.H.Y. & $\begin{array}{l}\text { REPORT ON THE } 25^{\mathrm{TH}} \text { PHD CONFERENCE IN } \\
\text { ECONOMICS AND BUSINESS }\end{array}$ \\
\hline 13.06 & Walker, A. and Tyers, R. & QUANTIFYING AUSTRALIA’S “THREE SPEED” BOOM \\
\hline 13.07 & Yu, F. and Wu, Y. & PATENT EXAMINATION AND DISGUISED PROTECTION \\
\hline 13.08 & Yu, F. and Wu, Y. & $\begin{array}{l}\text { PATENT CITATIONS AND KNOWLEDGE SPILLOVERS: } \\
\text { AN ANALYSIS OF CHINESE PATENTS REGISTER IN } \\
\text { THE US }\end{array}$ \\
\hline 13.09 & Chatterjee, I. and Saha, B. & BARGAINING DELEGATION IN MONOPOLY \\
\hline 13.10 & Cheong, T.S. and Wu, Y. & $\begin{array}{l}\text { GLOBALIZATION AND REGIONAL INEQUALITY IN } \\
\text { CHINA }\end{array}$ \\
\hline 13.11 & Cheong, T.S. and $\mathrm{Wu}, \mathrm{Y}$. & INEQUALITY AND CRIME RATES IN CHINA \\
\hline 13.12 & Robertson, P.E. and Ye, L. & ON THE EXISTENCE OF A MIDDLE INCOME TRAP \\
\hline 13.13 & Robertson, P.E. & THE GLOBAL IMPACT OF CHINA’S GROWTH \\
\hline 13.14 & $\begin{array}{l}\text { Hanaki, N., Jacquemet, N., } \\
\text { Luchini, S., and Zylbersztejn, A. }\end{array}$ & $\begin{array}{l}\text { BOUNDED RATIONALITY AND STRATEGIC } \\
\text { UNCERTAINTY IN A SIMPLE DOMINANCE SOLVABLE } \\
\text { GAME }\end{array}$ \\
\hline 13.15 & $\begin{array}{l}\text { Okatch, Z., Siddique, A. and } \\
\text { Rammohan, A. }\end{array}$ & $\begin{array}{l}\text { DETERMINANTS OF INCOME INEQUALITY IN } \\
\text { BOTSWANA }\end{array}$ \\
\hline 13.16 & Clements, K.W. and Gao, G. & $\begin{array}{l}\text { A MULTI-MARKET APPROACH TO MEASURING THE } \\
\text { CYCLE }\end{array}$ \\
\hline 13.17 & Chatterjee, I. and Ray, R. & $\begin{array}{l}\text { THE ROLE OF INSTITUTIONS IN THE INCIDENCE OF } \\
\text { CRIME AND CORRUPTION }\end{array}$ \\
\hline 13.18 & Fu, D. and Wu, Y. & $\begin{array}{l}\text { EXPORT SURVIVAL PATTERN AND DETERMINANTS } \\
\text { OF CHINESE MANUFACTURING FIRMS }\end{array}$ \\
\hline 13.19 & Shi, X., Wu, Y. and Zhao, D. & $\begin{array}{l}\text { KNOWLEDGE INTENSIVE BUSINESS SERVICES AND } \\
\text { THEIR IMPACT ON INNOVATION IN CHINA }\end{array}$ \\
\hline 13.20 & $\begin{array}{l}\text { Tyers, R., Zhang, Y. and } \\
\text { Cheong, T.S. }\end{array}$ & $\begin{array}{l}\text { CHINA'S SAVING AND GLOBAL ECONOMIC } \\
\text { PERFORMANCE }\end{array}$ \\
\hline 13.21 & Collins, J., Baer, B. and Weber, E.J. & $\begin{array}{l}\text { POPULATION, TECHNOLOGICAL PROGRESS AND THE } \\
\text { EVOLUTION OF INNOVATIVE POTENTIAL }\end{array}$ \\
\hline 13.22 & Hartley, P.R. & THE FUTURE OF LONG-TERM LNG CONTRACTS \\
\hline 13.23 & Tyers, R. & $\begin{array}{l}\text { A SIMPLE MODEL TO STUDY GLOBAL } \\
\text { MACROECONOMIC INTERDEPENDENCE }\end{array}$ \\
\hline
\end{tabular}




\begin{tabular}{|c|c|c|}
\hline 13.24 & McLure, M. & $\begin{array}{l}\text { REFLECTIONS ON THE QUANTITY THEORY: PIGOU IN } \\
1917 \text { AND PARETO IN 1920-21 }\end{array}$ \\
\hline 13.25 & Chen, A. and Groenewold, N. & $\begin{array}{l}\text { REGIONAL EFFECTS OF AN EMISSIONS-REDUCTION } \\
\text { POLICY IN CHINA: THE IMPORTANCE OF THE } \\
\text { GOVERNMENT FINANCING METHOD }\end{array}$ \\
\hline 13.26 & Siddique, M.A.B. & $\begin{array}{l}\text { TRADE RELATIONS BETWEEN AUSTRALIA AND } \\
\text { THAILAND: } 1990 \text { TO } 2011\end{array}$ \\
\hline 13.27 & Li, B. and Zhang, J. & $\begin{array}{l}\text { GOVERNMENT DEBT IN AN INTERGENERATIONAL } \\
\text { MODEL OF ECONOMIC GROWTH, ENDOGENOUS } \\
\text { FERTILITY, AND ELASTIC LABOR WITH AN } \\
\text { APPLICATION TO JAPAN }\end{array}$ \\
\hline 13.28 & Robitaille, M. and Chatterjee, I. & $\begin{array}{l}\text { SEX-SELECTIVE ABORTIONS AND INFANT } \\
\text { MORTALITY IN INDIA: THE ROLE OF PARENTS’ } \\
\text { STATED SON PREFERENCE }\end{array}$ \\
\hline 13.29 & Ezzati, P. & $\begin{array}{l}\text { ANALYSIS OF VOLATILITY SPILLOVER EFFECTS: } \\
\text { TWO-STAGE PROCEDURE BASED ON A MODIFIED } \\
\text { GARCH-M }\end{array}$ \\
\hline 13.30 & Robertson, P. E. & $\begin{array}{l}\text { DOES A FREE MARKET ECONOMY MAKE AUSTRALIA } \\
\text { MORE OR LESS SECURE IN A GLOBALISED WORLD? }\end{array}$ \\
\hline 13.31 & $\begin{array}{l}\text { Das, S., Ghate, C. and } \\
\text { Robertson, P. E. }\end{array}$ & $\begin{array}{l}\text { REMOTENESS AND UNBALANCED GROWTH: } \\
\text { UNDERSTANDING DIVERGENCE ACROSS INDIAN } \\
\text { DISTRICTS }\end{array}$ \\
\hline 13.32 & Robertson, P.E. and Sin, A. & $\begin{array}{l}\text { MEASURING HARD POWER: CHINA'S ECONOMIC } \\
\text { GROWTH AND MILITARY CAPACITY }\end{array}$ \\
\hline 13.33 & $\mathrm{Wu}, \mathrm{Y}$. & $\begin{array}{l}\text { TRENDS AND PROSPECTS FOR THE RENEWABLE } \\
\text { ENERGY SECTOR IN THE EAS REGION }\end{array}$ \\
\hline 13.34 & $\begin{array}{l}\text { Yang, S., Zhao, D., Wu, Y. and } \\
\text { Fan, J. }\end{array}$ & $\begin{array}{l}\text { REGIONAL VARIATION IN CARBON EMISSION AND } \\
\text { ITS DRIVING FORCES IN CHINA: AN INDEX } \\
\text { DECOMPOSITION ANALYSIS }\end{array}$ \\
\hline
\end{tabular}




\begin{tabular}{|c|c|c|}
\hline \multicolumn{3}{|c|}{$\begin{array}{l}\text { ECONOMICS DISCUSSION PAPERS } \\
2014\end{array}$} \\
\hline $\begin{array}{l}\text { DP } \\
\text { NUMBER }\end{array}$ & AUTHORS & TITLE \\
\hline 14.01 & $\begin{array}{l}\text { Boediono, Vice President of the Republic } \\
\text { of Indonesia }\end{array}$ & $\begin{array}{l}\text { THE CHALLENGES OF POLICY MAKING IN A } \\
\text { YOUNG DEMOCRACY: THE CASE OF INDONESIA } \\
\text { (52ND SHANN MEMORIAL LECTURE, 2013) }\end{array}$ \\
\hline 14.02 & Metaxas, P.E. and Weber, E.J. & $\begin{array}{l}\text { AN AUSTRALIAN CONTRIBUTION TO } \\
\text { INTERNATIONAL TRADE THEORY: THE } \\
\text { DEPENDENT ECONOMY MODEL }\end{array}$ \\
\hline 14.03 & Fan, J., Zhao, D., Wu, Y. and Wei, J. & $\begin{array}{l}\text { CARBON PRICING AND ELECTRICITY MARKET } \\
\text { REFORMS IN CHINA }\end{array}$ \\
\hline 14.04 & McLure, M. & $\begin{array}{l}\text { A.C. PIGOU’S MEMBERSHIP OF THE } \\
\text { 'CHAMBERLAIN-BRADBURY’ COMMITTEE. } \\
\text { PART I: THE HISTORICAL CONTEXT }\end{array}$ \\
\hline 14.05 & McLure, M. & $\begin{array}{l}\text { A.C. PIGOU’S MEMBERSHIP OF THE } \\
\text { 'CHAMBERLAIN-BRADBURY’ COMMITTEE. } \\
\text { PART II: ‘TRANSITIONAL’AND ‘ONGOING’ ISSUES }\end{array}$ \\
\hline 14.06 & King, J.E. and McLure, M. & HISTORY OF THE CONCEPT OF VALUE \\
\hline 14.07 & Williams, A. & $\begin{array}{l}\text { A GLOBAL INDEX OF INFORMATION AND } \\
\text { POLITICAL TRANSPARENCY }\end{array}$ \\
\hline 14.08 & Knight, K. & $\begin{array}{l}\text { A.C. PIGOU'S THE THEORY OF UNEMPLOYMENT } \\
\text { AND ITS CORRIGENDA: THE LETTERS OF } \\
\text { MAURICE ALLEN, ARTHUR L. BOWLEY, RICHARD } \\
\text { KAHN AND DENNIS ROBERTSON }\end{array}$ \\
\hline 14.09 & Cheong, T.S. and Wu, Y. & $\begin{array}{l}\text { THE IMPACTS OF STRUCTURAL RANSFORMATION } \\
\text { AND INDUSTRIAL UPGRADING ON REGIONAL } \\
\text { INEQUALITY IN CHINA }\end{array}$ \\
\hline 14.10 & $\begin{array}{l}\text { Chowdhury, M.H., Dewan, M.N.A., } \\
\text { Quaddus, M., Naude, M. and } \\
\text { Siddique, A. }\end{array}$ & $\begin{array}{l}\text { GENDER EQUALITY AND SUSTAINABLE } \\
\text { DEVELOPMENT WITH A FOCUS ON THE COASTAL } \\
\text { FISHING COMMUNITY OF BANGLADESH }\end{array}$ \\
\hline 14.11 & Bon, J. & $\begin{array}{l}\text { UWA DISCUSSION PAPERS IN ECONOMICS: THE } \\
\text { FIRST } 750\end{array}$ \\
\hline 14.12 & Finlay, K. and Magnusson, L.M. & $\begin{array}{l}\text { BOOTSTRAP METHODS FOR INFERENCE WITH } \\
\text { CLUSTER-SAMPLE IV MODELS }\end{array}$ \\
\hline 14.13 & Chen, A. and Groenewold, N. & $\begin{array}{l}\text { THE EFFECTS OF MACROECONOMIC SHOCKS ON } \\
\text { THE DISTRIBUTION OF PROVINCIAL OUTPUT IN } \\
\text { CHINA: ESTIMATES FROM A RESTRICTED VAR } \\
\text { MODEL }\end{array}$ \\
\hline 14.14 & Hartley, P.R. and Medlock III, K.B. & $\begin{array}{l}\text { THE VALLEY OF DEATH FOR NEW ENERGY } \\
\text { TECHNOLOGIES }\end{array}$ \\
\hline 14.15 & $\begin{array}{l}\text { Hartley, P.R., Medlock III, K.B., } \\
\text { Temzelides, T. and Zhang, X. }\end{array}$ & $\begin{array}{l}\text { LOCAL EMPLOYMENT IMPACT FROM COMPETING } \\
\text { ENERGY SOURCES: SHALE GAS VERSUS WIND } \\
\text { GENERATION IN TEXAS }\end{array}$ \\
\hline 14.16 & Tyers, R. and Zhang, Y. & $\begin{array}{l}\text { SHORT RUN EFFECTS OF THE ECONOMIC REFORM } \\
\text { AGENDA }\end{array}$ \\
\hline
\end{tabular}

